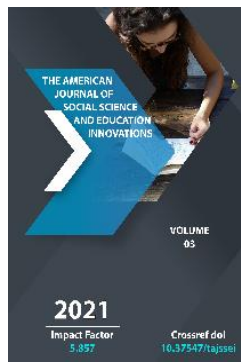

\title{
Lexical-Semantic Transformation Of Units Related To Images Of Imaginary Animals Found In Korean Fairy Tales
}

\author{
Muqaddaskhon Taylanova \\ Ph.D. Student, Tashkent State University Of Oriental Studies, Uzbekistan
}

Journal Website:

https://theamericanjou

rnals.com/index.php/ta

jssei

Copyright: Original content from this work may be used under the terms of the creative commons attributes 4.0 licence.

\section{ABSTRACT}

Imaginary animals have long been shaped as positive or negative images in fairy tales, based on human lifestyle, culture, worldview, and imagination. "Man is always imagining, inventing all sorts of strange things.It is these characteristics of the ancestors that have played a key role in the formation of your various images." Imaginary animals are often portrayed as good, just, and honest. Through imaginary images, people create their own perfect human being. The main goal is to create the image that he wants in life, that will benefit the people.

\section{KEYWORDS}

Korean fairy tales, forest in the mountains, relationships, magic power, folklore, imaginary animal, concept of celestial.

\section{INTRODUCTION}

For this reason, imaginary images play a key role in fairy tales. The imaginary animals in Korean fairy tales are not very similar to the characters in Uzbek folk tales. "We are fascinated by the fact that the heroes of fairy tales have the ability to die and be resurrected. It is true that the giving of life to a dead person is considered an expression of the worldview of our ancient ancestors. But at the same time, it is worth noting that the fact that the soul of a dead person is inseparable from the house in which he lived for days, months and years, visible to relatives in various forms and situations, has become a common means of 
depiction in fairy tales. In the minds of the people, any good deed must be rewarded." 1

The image of "tokkebi" in Korean fairy tales is also one of the imaginary. Scientifically, this image is said to have appeared in Korea in the 1970s. Scientists are trying to determine in which fairy tales this image occurs. ${ }^{2}$

As a forest spirit, the tokkebi often appears in the evening, at sunrise and sunset. This image appears on people's roads, in difficult situations, in the mountains.

The forest canopy is depicted as a helping, rewarding image. The agreement between Tokkebi and the man is the end of the story.

Tokkebi is embodied in Korean fairy tales as follows:

1. Appearance: Man, fire, turns into various objects;

2. Weapon: Often carries an ax;

3. Habitat: forest in the mountains, close to people;

4. Relationships with people: They know how to cheat, how to reward;

5. Magic Power: They have supernatural magic.

For example, the image of tokkebi is depicted in a Korean magical folk tale called "도깨비를 물리친 사물놀이" (the samul nori that defeated Tokkebi):

http://turizm.kasaba.uz/uz/uzbek_legends_and_mythe s/fairy_tales

2 Ли Джеджун. Былички о лесном духе в корейской и русской фольклорной традициях: опыт сравнительной типоло-гии. - диссер., СПб, 2011. C. 9
1.그때, 휘이익 바람이 불며 벼들이 몹시 흔들리기 시작했어요. 도깨비들이 나타난 것이에요. 훈이와 아이들은 매우 놀랐지만 꽹과리를 치기 시작했어요. 깨갱 깽 깽깽 그러자 하늘이 천둥번개가 치는 것처럼 우르릉 쾅쾅 요동을 치기 시작했어요.3

Translation:

"It simply came to our notice then that the wind was blowing and the barley was moving. The funnel and the children began to play the kkvengkvari ${ }^{4}$ even though they were very surprised. Then there was thunder and lightning in the sky."

In folklore, the tokkebi is often depicted as a creature with human features, with its entire body covered with thick hair. $\mathrm{He}$ is depicted dressed in traditional Korean costumes and often carries a wooden hammer. ${ }^{5}$

2. 도깨비들은 무서워서 덜덜 떨었어요. 그리고 훈이와 민이, 순덕이와 덕이가 모두 함께 사물놀이를 하며 하나의 소리로 울려 지자 도깨비들이 회오리바람처럼 빙빙 돌기 시작했어요.

아이들은 더욱 신명나게 악기를 치기 시작했어요. 마침내는 도깨비들이 슬금슬금 저 하늘 멀리로 도망치기 시작했답니다. “우와, 우리가 도깨비를 물리쳤다!” 훈이와

${ }^{3} \mathrm{http}: / / 18$ children.president.pa.go.kr/mobile/our_spac e/fairy_tales.php?srh\%5Bcategory\%5D=07\&srh\%5 Bpage $\% 5 \mathrm{D}=3$

${ }^{4}$ Little Korean national instrument played with a wooden stick..

${ }^{5}$ [Elektron manba] URL:

https://brunch.co.kr/@onestepculture/40 
아이들은 손뼉을 치며 즐거워했답니다. 다음 날 아침이 되자 쓰러졌던 벼들이 다시 일어났어요.

Translation:

"It simply came to our notice then. When "Huni and Mini, Sundeoki and Deoki"6 played Samul nori together, the tokkebi began to spin like a rabbit.

The children began to play musical instruments with even more excitement. Eventually, the Tokkebi tried to escape into the sky. "Hi, we beat the crap out of you!" Huni and the children clapped their hands and had fun. The next morning, the bent barley rose again."

In Korean folklore, the image of "tokkebi" has different meanings: "tokkebi" is embodied as good and evil, the spirit of the forest?

No image in the Uzbek language is adequate to the image of Tokkebi. Therefore, it is advisable to translate this image in its original form. It is found in other languages' translations of the image as "goblin". However, in the Uzbek language, this image was considered a national word because it was not formed.

"Magical tales prove that human imagination is infinite. They were the hunting ground of our forefathers, who were troubled by the worries of life. Telling a fairy tale or listening to it with pleasure gave our ancestors the will and confidence in the future. At the same time, it has served as evidence that folklore is a verbal

\footnotetext{
${ }^{6}$ Koreys ertagidagi bolalarning ismlari

${ }^{7}$ Пропп В.Я. Исторические корни волшебной сказки/научная редакция, текстологический комментарий И.В. Пешкова. - Издательство «Лабиринт», М., 2000. С. 136 8

http://turizm.kasaba.uz/uz/uzbek_legends_and_mythe s/fairy_tales
}

art. The kata in the nation has become a legacy of instruction for the next generation." 8

In Korea, another imaginary animal is the giraffe. Despite being a wild animal, it is considered by Koreans to be an imaginary animal. According to Korean mythology, the most perfect animal in the world is "기린" (kirin) - an imaginary animal that embodies the synthesis of male and female principles ("ki" male, "rin" - female). It is said to have a cow-like tail and a single soft horn.

"The giraffe embodies the five original elements of all things: water, fire, wood, metal, and earth. At the same time, it reflects the axiological values of the ancient Koreans. Kirin is a symbol of peace, joy, honesty and integrity. According to the data, in 404-406 AD, the image of "kirin" was based on the male and female principles of the universe ("yang" and "yum"), the five primary elements (water, fire, wood, metal and earth), the universal and human. reflects the unity of perfection (the concept of celestial "li") "9.

\section{REFERENCES}

1. Ли Джеджун. Былички о лесном духе в корейской и русской фольклорной традициях: опыт сравнительной типоло-гии. - диссер., СПб, 2011. С. 9.

2. Пропп В.Я. Исторические корни волшебной сказки/научная редакция, текстологический комментарий И.В. Пешкова. - Издательство «Лабиринт», М., 2000. С. 136.

\footnotetext{
${ }^{9}$ Хан В. С. Древнекорейская мифология и ранние формы религииһttps://koryosaram.ru/mifologicheskie-i-religiozno-filosofskiepredstavleniya-v-e-pohu-drevnosti-i-rannefeodal-nojgosudarstvennosti-na-korejskom-poluostrove/,2009
} 
The American Journal of Social Science and Education Innovations (ISSN - 2689-100x)

Published: August 31, 2021 | Pages: 37-40

Doi : https://doi.org/10.37547/tajssei/Volumeo3Issueo8-09

3. Хан В. С. Древнекорейская

мифология и ранние формы

религииһttps://koryo-

saram.ru/mifologicheskie-i-religiozno-

filosofskie-predstavleniya-v-e-pohu-

drevnosti-i-rannefeodal-noj-

gosudarstvennosti-na-korejskom-

poluostrove/,2009.

4. https://brunch.co.kr/@onestepculture/

40.

5. http://turizm.kasaba.uz/uz/uzbek_lege nds_and_mythes/fairy_tales.

6. http://18children.president.pa.go.kr/m obile/our_space/fairy_tales.php?srh\%5

Bcategory\%5D=07\&srh\%5 Bpage\%5D=3

7. Ismatullayeva, Nargiza. (2021).

PHRASEOLOGY WITH ZOONYMIC COMPONENTS OF "DRAGON" AND "TIGER" IN CHINESE AND KOREAN LANGUAGES. 183-189. 10.37547/ocl-01-

35. 